\title{
Brazilian Journal \\ of Chemical

\section{LIQUID - LIQUID EQUILIBRIA OF THE WATER + BUTYRIC ACID + DECANOL TERNARY SYSTEM}

\author{
Ş. İ. Kırbaşlar \\ School of Engineering, Chemical Engineering Department, \\ Istanbul University, 34320 Avcilar - Istanbul, Turkey \\ E-mail: krbaslar@istanbul.edu.tr.
}

(Received: April 3, 2004 ; Accepted: March 7, 2006)

\begin{abstract}
Liquid-liquid equilibrium (LLE) data for the water + butyric acid + decanol ternary system were determined experimentally at temperatures of $298.15,308.15$ and $318.15 \mathrm{~K}$. Complete phase diagrams were obtained by determining the solubility curve and the tie lines. The reliability of the experimental tie line data was confirmed with the Othmer-Tobias correlation. The UNIFAC method was used to predict the phase equilibrium of the system using the interaction parameters for groups $\mathrm{CH}_{3}, \mathrm{CH}_{2}, \mathrm{COOH}, \mathrm{OH}$ and $\mathrm{H}_{2} \mathrm{O}$ determined experimentally. Distribution coefficients and separation factors were evaluated for the immiscibility region.

Keywords: Liquid-liquid equilibria; Butyric acid, Decanol; UNIFAC method.
\end{abstract}

\section{INTRODUCTION}

Interest in, solvent and reactive extraction techniques is currently growing. This results from their possible applications not only in the chemical industry, but also in the biotechnological production of some substances. Production of organic acids such as acetic, citric, lactic, propionic and butyric acids can be given as an example. Extraction can be employed not an only in downstream separation but also in combination with fermentation (Wardell and King, 1978; Hegazi, 1984; Fahim et al., 1992; Arce et al., 1995; Fahim and Al-Muhtaseb, 1996; Fahim et al., 1997; Sólimo et al., 1997; Colombo et al., 1999; Aljimaz et al., 2000; Taghikhani et al., 2001; Trevor et al., 2001; İnce and Kırbaşlar, 2002; İnce, 2005).

Butyric acid and some of its esters are used in the food and perfumes industries because of their aromatic properties. Butyric acid is also used in the pharmaceutical industry. Many processes have already been proposed for butyrate production by fermentation (Zigová and Šturdik, 2000). Nevertheless, fermentation processes have not yet been used commercially because of low product mass concentrations in the fermentation broth (20-30 $\mathrm{g} / \mathrm{L}$ ) and also because of the acetate that is produced simultaneously with butyrate. Presently, butyric acid is mostly produced synthetic from petrochemicals. However, the use of butyric acid or its esters as additives, in particular in the food or cosmetic industries, makes its origin important since consumers prefer natural products (Zigová et al., 1999; Zigová and Šturdik, 2000). A detailed evaluation of solvents for the extraction of butyric acid is not available in the literature (except in Zigová et al., 1996). They screened 14 solvents for the extraction of butyric acid and a tertiary amine in different diluents.

The real behaviour of fluid mixtures can be calculated with the help of activity coefficients. The

*To whom correspondence should be addressed 
correct description of the dependence on temperature, pressure and composition in multicomponent systems requires reliable thermodynamic models. The UNIFAC model was developed by Fredenslund et al. (1975). A special UNIFAC version for the prediction of liquid-liquid equilibria was published by Magnussen et al. (1981). The UNIFAC model for the estimation of activity coefficients is based on the concept that a liquid mixture may be considered a solution of structural units from which the molecules are formed, rather than a solution of the molecules themselves. It has the advantage of being able to form a very large number of molecules from a relatively small set of structural units. The structural units in the calculation method are called subgroups. The mole fractions, $\mathrm{X}^{\mathrm{E}}{ }_{\mathrm{i}}$ and $\mathrm{X}^{\mathrm{R}}{ }_{\mathrm{i}}$, of LLE phases can be calculated using the following equation:

$\gamma_{i}^{E} X_{i}^{E}=\gamma_{i}^{R} X_{i}^{R}$

This study is part of a research program on the recovery of butyric acid from dilute aqueous solutions using solvents with high boiling points. In this paper, we report LLE results for the water + butyric acid + decanol ternary systems for which no such data were available.

\section{EXPERIMENTAL}

\section{Materials}

Butyric acid and decanol were purchased from Merck and were of $>99 \%(w / w)$ and $99 \%(w / w)$ purities, respectively. Butyric acid and decanol were used without further purification. GC analysis did not detect any appreciable peaks of impurities. Deionised water was further distilled before use. Refractive indexes were measured with an AbbéHilger refractometer; its stated accuracy is $\pm 5 \times 10^{-4}$. Densities were measured with an Anton Paar densimeter (Model 4500). Boiling point measurements were obtained with a Fischer boiling point apparatus. The estimated uncertainties in the density and boiling point measurements were $\pm 10^{-5} \mathrm{~g} / \mathrm{cm}^{3}$ and $\pm 0.1 \mathrm{~K}$, respectively. The measured physical properties are listed in Table 1, along with values from the literature (Lide, 2002).

Table 1: Physical properties of the chemicals used in the experiments.

\begin{tabular}{|c|c|c|c|}
\hline Chemical & $\begin{array}{l}\rho^{293.15 K} \\
\left(\mathrm{~g} / \mathrm{cm}^{3}\right)\end{array}$ & $\eta_{D}^{293.15 K}$ & $\begin{array}{c}\text { b.p. } \\
(101.325 \mathrm{kPa} / \mathrm{K})\end{array}$ \\
\hline Water & $\begin{array}{r}0.997^{\mathrm{a}^{*}} \\
0.9999+0.0001^{\mathrm{b}}\end{array}$ & $\begin{array}{r}1.3325^{\mathrm{a}^{*}} \\
13324+0.0005^{\mathrm{b}}\end{array}$ & $\begin{array}{r}373.15^{\mathrm{a}} \\
373+01^{\mathrm{b}}\end{array}$ \\
\hline & $0.9528^{\mathrm{a}^{*}}$ & $1.3969^{\mathrm{a}}$ & $436.90^{\mathrm{a}}$ \\
\hline Butyric acid & $0.9601 \pm 0.0001^{\mathrm{b}}$ & $1.3970 \pm 0.0005^{\mathrm{b}}$ & $436.4 \pm 0.1^{\mathrm{b}}$ \\
\hline & $0.8297^{\mathrm{a}}$ & $1.4372^{\mathrm{a}}$ & $504.25^{\mathrm{a}}$ \\
\hline Decanol & $0.8303 \pm 0.0001^{\mathrm{b}}$ & $1.4373 \pm 0.0005^{\mathrm{b}}$ & $503.7 \pm 0.1^{\mathrm{b}}$ \\
\hline
\end{tabular}

${ }^{\mathrm{a}}$ literature (Lide, 2002)

${ }^{\mathrm{b}}$ this work

at $298.15 \mathrm{~K}$

\section{Procedure}

Three different temperatures $(298.15,308.15$ and $318.15 \mathrm{~K})$ were selected to study the ternary equilibrium system in order to observe the evaluation of the binodal curves and tie lines. At each temperature, individual solubility curves were determined by the cloud-point method in the magnetically stirred equilibrium cell. The equilibrium cell is given in Figure 1. The end point was determined by observing the transition from a homogenous to a heterogeneous solution.

The mutual solubilities of the water + decanol system were also determined by the cloud-point method. A weighed amount of one component was placed in the cell; then the other component was added until a permanent heterogeneity had been observed.

Tie-line data were obtained by preparing ternary mixtures (water + butyric acid + decanol) of known overall compositions lying within the two-phase region in a flask. After being stirred vigorously, the mixture was allowed to reach equilibrium in a shaker $(4 \mathrm{~h})$ at a constant temperature. Then the contents were immediately allowed to enter the equilibrium cell equipped with an isothermal jacket; after the complete separation of the phases $(8 \mathrm{~h})$, a suitable amount of each layer was removed for detailed analysis. The temperature of the equilibrium cell 
was measured with an electronically controlled thermostat with an accuracy of $\pm 0.1 \mathrm{~K}$. All mixtures were prepared by weighing with a Mettler scale accurate to $\pm 10^{-4} \mathrm{~g}$. The solvent was added with an automated microburet (Methrom) with an accuracy of $5 \times 10^{-3} \mathrm{~cm}^{3}$.

\section{Analysis}

The liquid samples were analysed with a Gas Chromatograph (Hewlett Packard GC, Model 6890 Series), equipped with a thermal conductivity detector (TCD) for the quantitative determination of water, butyric acid and decanol. A 15-m long HPPlot $Q$ column $(0.320 \mathrm{~mm}$ i.d., $0.2 \mu \mathrm{m}$ film thickness) was used for a temperature-programmed analysis. Column temperature was increased from $383 \mathrm{~K}(5 \mathrm{~min})$ to $451 \mathrm{~K}$ at $10 \mathrm{~K} / \mathrm{min}$ and to $523 \mathrm{~K}$ (2 $\min )$ at $25 \mathrm{~K} / \mathrm{min}$. A split ratio of 100:1 was used for injection. The detector was a TCD. The injector temperature was $523 \mathrm{~K}$ and the detector temperature was $473 \mathrm{~K}$. The flow rate of the carrier gas, nitrogen, was kept at $6 \mathrm{~cm}^{3} / \mathrm{min}$ and the injected volume of liquid sample was $1 \mu \mathrm{L}$. Samples with known compositions were used to calibrate the instrument in the composition range of interest.

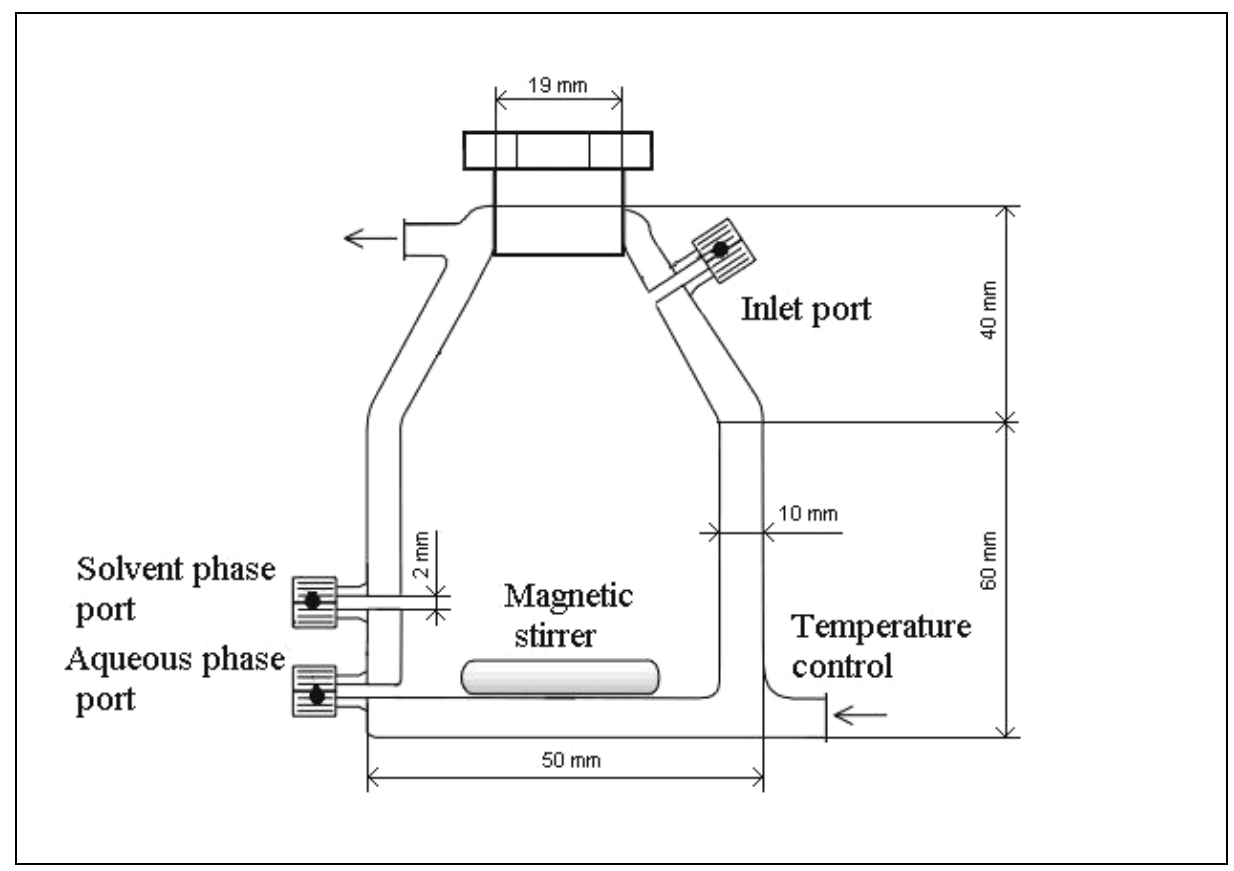

Figure 1: Liquid-liquid equilibrium cell.

\section{RESULTS AND DISCUSSION}

The experimental binodal curve and tie-line data on the water + butyric acid + decanol ternary system at 298.15, 308.15 and 318.15 $\mathrm{K}$ are given in Tables 2 and 3, respectively. The experimental LLE data and predicted tie lines at each temperature were plotted and shown in Figures 2, 3, and 4. As can be seen in Figures 2, 3 and 4, it was found that decanol was insoluble in water, but miscible with butyric acid. Distribution coefficients, $\left(\mathrm{d}_{\mathrm{i}}\right)$, for water $(\mathrm{i}=1)$, butyric acid $(\mathrm{i}=2)$ and separation factors $(\mathrm{s})$, were calculated as follows:

$$
\begin{aligned}
& \mathrm{d}_{\mathrm{i}}=\frac{\mathrm{w}_{\mathrm{i} 3}}{\mathrm{w}_{\mathrm{i} 1}} \\
& \mathrm{~s}=\frac{\text { distribution coefficient of butyric acid }}{\text { distribution coefficient of water }}= \\
& =\left(\mathrm{w}_{23} / \mathrm{w}_{13}\right)_{\text {solvent-rich phase }} /\left(\mathrm{w}_{21} / \mathrm{w}_{11}\right)_{\text {water-rich phase }}
\end{aligned}
$$


Table 2: Experimental binodal curve data for the water (1) + butyric acid (2) + decanol (3) system at each temperature.

\begin{tabular}{|c|c|c|c|c|c|c|c|c|}
\hline \multicolumn{4}{|c}{ T= 298.15 K } & \multicolumn{3}{c|}{$\mathbf{T}=\mathbf{3 0 8 . 1 5} \mathbf{K}$} & \multicolumn{3}{c|}{$\mathbf{T}=\mathbf{3 1 8 . 1 5 ~ K}$} \\
\hline \multicolumn{2}{|c|}{ mass fraction (w/w, \%) } & \multicolumn{2}{c|}{ mass fraction (w/w, \%) } & \multicolumn{2}{c|}{ mastion (w/w, \%) } \\
\hline water & $\begin{array}{c}\text { butyric } \\
\text { acid }\end{array}$ & decanol & water & $\begin{array}{c}\text { butyric } \\
\text { acid }\end{array}$ & decanol & water & $\begin{array}{c}\text { butyric } \\
\text { acid }\end{array}$ & decanol \\
\hline 2.34 & 0.00 & 97.66 & 2.83 & 0.00 & 97.17 & 3.50 & 0.00 & 96.50 \\
4.47 & 19.33 & 76.20 & 3.50 & 11.50 & 85.95 & 4.42 & 10.94 & 84.63 \\
5.70 & 28.80 & 65.50 & 4.45 & 20.11 & 75.44 & 5.10 & 19.77 & 75.13 \\
7.37 & 36.87 & 55.77 & 6.11 & 28.72 & 65.17 & 6.35 & 28.37 & 65.28 \\
8.84 & 44.20 & 46.96 & 8.15 & 36.74 & 55.11 & 8.27 & 36.16 & 55.56 \\
11.91 & 51.77 & 36.32 & 10.03 & 44.19 & 45.78 & 10.27 & 44.19 & 45.54 \\
15.02 & 56.79 & 28.19 & 15.41 & 56.26 & 28.33 & 14.78 & 53.08 & 32.14 \\
21.31 & 61.01 & 17.68 & 22.43 & 59.67 & 17.91 & 27.25 & 58.09 & 14.66 \\
33.17 & 58.94 & 7.88 & 28.31 & 59.73 & 11.97 & 38.27 & 53.83 & 7.90 \\
39.33 & 55.49 & 5.17 & 37.36 & 55.64 & 7.00 & 49.14 & 45.92 & 4.94 \\
49.47 & 47.37 & 3.16 & 49.46 & 46.77 & 3.77 & 59.39 & 37.48 & 3.13 \\
59.54 & 38.54 & 1.93 & 59.44 & 38.03 & 2.53 & 69.12 & 29.15 & 1.73 \\
69.87 & 29.01 & 1.12 & 69.7 & 28.87 & 1.43 & 79.76 & 19.92 & 0.32 \\
81.66 & 18.05 & 0.29 & 79.28 & 20.24 & 0.48 & 89.08 & 10.77 & 0.16 \\
99.68 & 0.00 & 0.32 & 99.68 & 0.00 & 0.32 & 99.69 & 0.00 & 0.31 \\
\hline
\end{tabular}

Table 3: Experimental tie lines of water (1) + butyric acid (2) + decanol (3) system at each temperature.

\begin{tabular}{|c|c|c|c|c|c|}
\hline \multicolumn{3}{|c|}{ water-rich phase $(w / w, \%)$} & \multicolumn{3}{|c|}{ solvent-rich phase (w/w, \%) } \\
\hline water & butyric acid & decanol & water & butyric acid & decanol \\
\hline \multicolumn{6}{|c|}{$298.15 \mathrm{~K}$} \\
\hline 98.14 & 1.48 & 0.38 & 2.70 & 8.47 & 88.83 \\
\hline 96.82 & 2.79 & 0.39 & 3.80 & 16.13 & 80.07 \\
\hline 95.52 & 4.08 & 0.40 & 4.80 & 22.85 & 72.35 \\
\hline 94.39 & 5.20 & 0.41 & 5.50 & 29.01 & 65.49 \\
\hline 93.36 & 6.22 & 0.42 & 7.00 & 34.13 & 58.87 \\
\hline 92.41 & 7.16 & 0.43 & 7.50 & 40.39 & 52.11 \\
\hline 91.40 & 8.16 & 0.44 & 9.00 & 45.06 & 45.94 \\
\hline 90.44 & 9.11 & 0.45 & 11.00 & 49.37 & 39.63 \\
\hline 89.95 & 9.60 & 0.45 & 12.50 & 52.35 & 35.15 \\
\hline \multicolumn{6}{|c|}{$308.15 \mathrm{~K}$} \\
\hline 98.05 & 1.57 & 0.38 & 2.90 & 9.17 & 87.93 \\
\hline 96.72 & 2.89 & 0.39 & 3.60 & 16.06 & 80.34 \\
\hline 95.50 & 4.10 & 0.40 & 4.80 & 23.16 & 72.04 \\
\hline 94.18 & 5.41 & 0.41 & 5.80 & 29.53 & 64.67 \\
\hline 93.35 & 6.23 & 0.42 & 6.20 & 33.87 & 59.93 \\
\hline 92.24 & 7.33 & 0.43 & 8.80 & 40.85 & 50.35 \\
\hline 91.73 & 7.83 & 0.44 & 10.10 & 43.92 & 45.98 \\
\hline 90.61 & 8.94 & 0.45 & 11.90 & 49.39 & 38.71 \\
\hline 90.04 & 9.51 & 0.45 & 13.50 & 52.80 & 33.70 \\
\hline \multicolumn{6}{|c|}{$318.15 \mathrm{~K}$} \\
\hline 98.30 & 1.54 & 0.16 & 4.60 & 9.76 & 85.64 \\
\hline 97.13 & 2.70 & 0.17 & 4.80 & 16.15 & 79.05 \\
\hline 95.80 & 4.02 & 0.18 & 5.00 & 22.86 & 72.14 \\
\hline 94.64 & 5.17 & 0.19 & 5.80 & 29.42 & 64.78 \\
\hline 93.57 & 6.23 & 0.20 & 7.50 & 34.66 & 57.84 \\
\hline 92.79 & 7.00 & 0.21 & 9.40 & 40.96 & 49.64 \\
\hline 91.52 & 8.26 & 0.22 & 10.20 & 44.46 & 45.34 \\
\hline 91.30 & 8.47 & 0.23 & 11.50 & 47.74 & 40.76 \\
\hline 90.13 & 9.63 & 0.24 & 13.50 & 52.54 & 33.96 \\
\hline
\end{tabular}




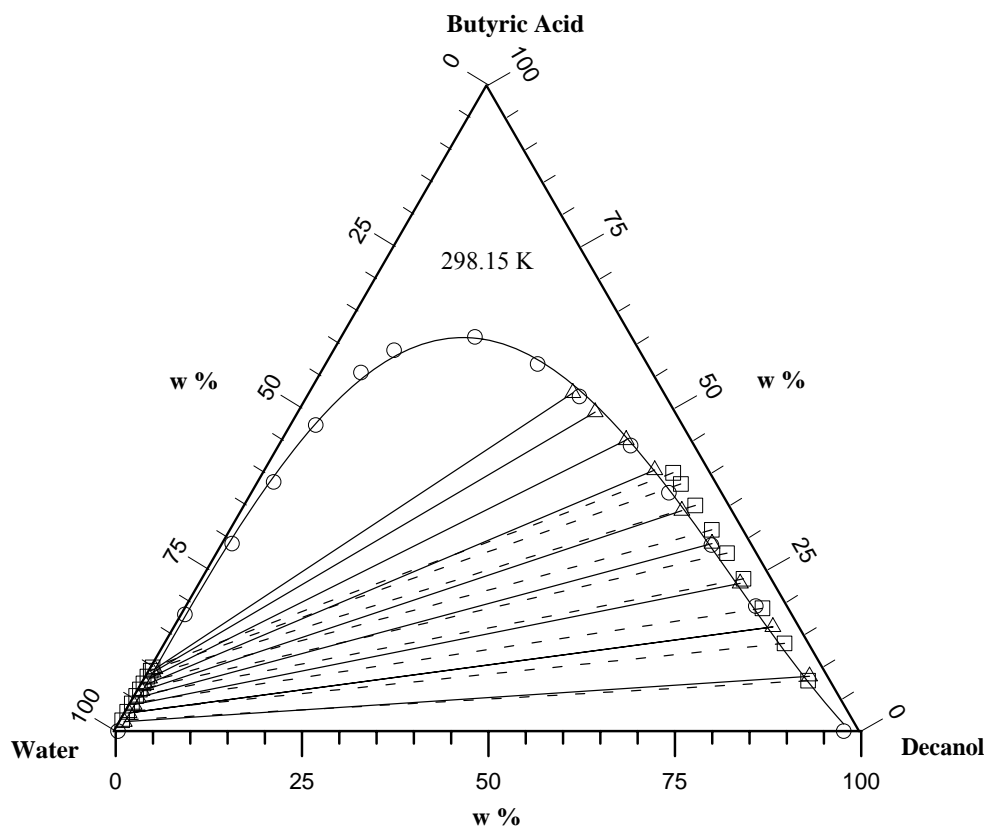

Figure 2: Ternary diagram for LLE of water (1) + butyric acid (2) + decanol (3) at $298.15 \mathrm{~K} ;-0-$ experimental solubility curve; $-\Delta$ - experimental tie lines; -- $\square--$ calculated (UNIFAC method) tie lines.

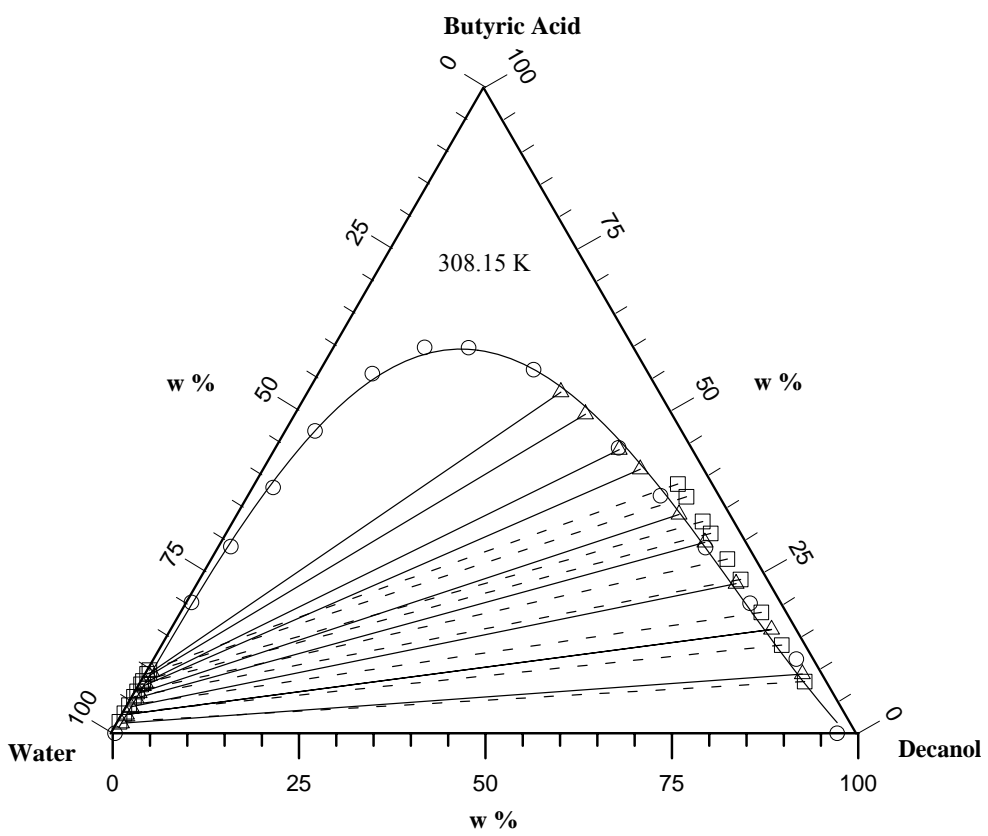

Figure 3: Ternary diagram for LLE of water (1) + butyric acid (2) + decanol (3) at $308.15 \mathrm{~K} ;-0-$ experimental solubility curve; $-\Delta$ - experimental tie lines; -- $\square--$ calculated (UNIFAC method) tie lines. 


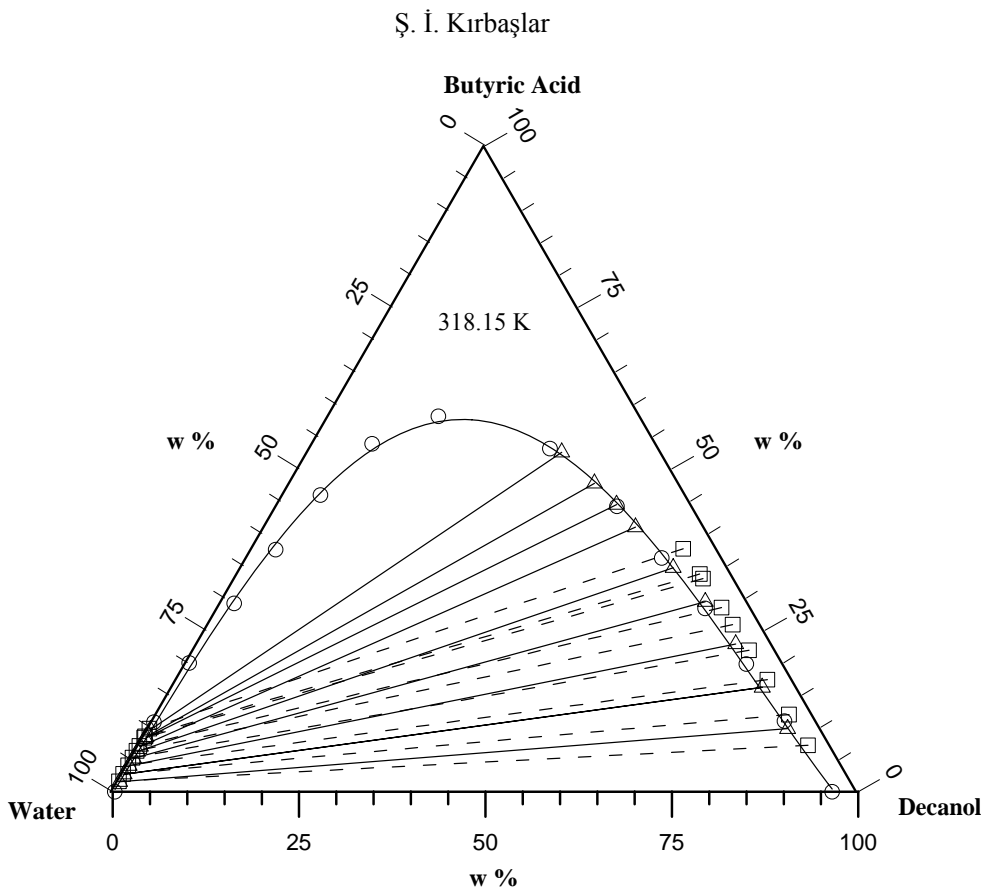

Figure 4: Ternary diagram for LLE of water (1) + butyric acid (2) + decanol (3) at $318.15 \mathrm{~K} ;-0-$ experimental solubility curve; $-\Delta$ - experimental tie lines; -- -- calculated (UNIFAC method) tie lines.

The distribution coefficients and separation factors for each temperature are given in Table 4. The effectiveness of extraction of butyric acid by decanol is given by its separation factor, which is a measure of the ability of decanol to separate the butyric acid from water. This quantity is found to be greater than 1 (varying from 36 to 208) for the system reported here, which means that extraction of butyric acid by decanol is possible. The separation factor is not constant over the whole heterogeneous region. The extraction power of the solvent at each temperature, plots of $\mathrm{d}_{2}$ vs. $\mathrm{w}_{21}$ and $\mathrm{s} v \mathrm{~s}$. $\mathrm{w}_{21}$, are shown in Figures 5 and 6, respectively.

The reliability of experimentally measured tie lines can be ascertained by applying the OthmerTobias correlation at each temperature (Othmer and Tobias, 1942). Othmer-Tobias plots were constructed of $\ln \left(\left(1-\mathrm{w}_{33}\right) / \mathrm{w}_{33}\right)$ vs. $\ln \left(\left(1-\mathrm{w}_{11}\right) / \mathrm{w}_{11}\right)$, and a correlation is at $298.15 \mathrm{~K}$ shown in Figure 7. In Figure 7, the linearity of the plot indicates the degree of consistency of the related data. Similar results were observed for the rest of the data.

$$
\ln \left(\left(1-\mathrm{w}_{11}\right) / \mathrm{w}_{11}\right)=\mathrm{a}+\mathrm{b} \ln \left(\left(1-\mathrm{w}_{33}\right) / \mathrm{w}_{33}\right)
$$

Table 4: Distribution coefficients, $d_{i}$, of water (1) - butyric acid (2) and separation factors, $s$, at each temperature.

\begin{tabular}{|c|c|c|c|c|c|c|c|c|}
\hline \multicolumn{3}{|c|}{$\mathbf{2 9 8 . 1 5} \mathbf{~ K}$} & \multicolumn{3}{c|}{$\mathbf{3 0 8 . 1 5} \mathbf{K}$} & \multicolumn{3}{c|}{ 318.15 K } \\
\hline $\mathbf{d}_{\mathbf{1}}$ & $\mathbf{d}_{\mathbf{2}}$ & $\mathbf{s}$ & $\mathbf{d}_{\mathbf{1}}$ & $\mathbf{d}_{\mathbf{2}}$ & $\mathbf{s}$ & $\mathbf{d}_{\mathbf{1}}$ & $\mathbf{d}_{\mathbf{2}}$ & $\mathbf{s}$ \\
\hline 0.028 & 5.736 & 208 & 0.034 & 5.833 & 173 & 0.047 & 6.323 & 135 \\
0.039 & 5.788 & 147 & 0.037 & 5.554 & 149 & 0.049 & 5.982 & 121 \\
0.044 & 5.602 & 127 & 0.044 & 5.646 & 128 & 0.052 & 5.680 & 109 \\
0.058 & 5.580 & 96 & 0.062 & 5.460 & 89 & 0.061 & 5.693 & 93 \\
0.075 & 5.484 & 73 & 0.066 & 5.434 & 82 & 0.080 & 5.564 & 69 \\
0.081 & 5.637 & 69 & 0.095 & 5.574 & 58 & 0.101 & 5.850 & 58 \\
0.098 & 5.523 & 56 & 0.110 & 5.607 & 51 & 0.111 & 5.380 & 48 \\
0.122 & 5.418 & 45 & 0.137 & 5.522 & 40 & 0.126 & 5.633 & 45 \\
0.139 & 5.455 & 39 & 0.150 & 5.554 & 37 & 0.150 & 5.454 & 36 \\
\hline
\end{tabular}




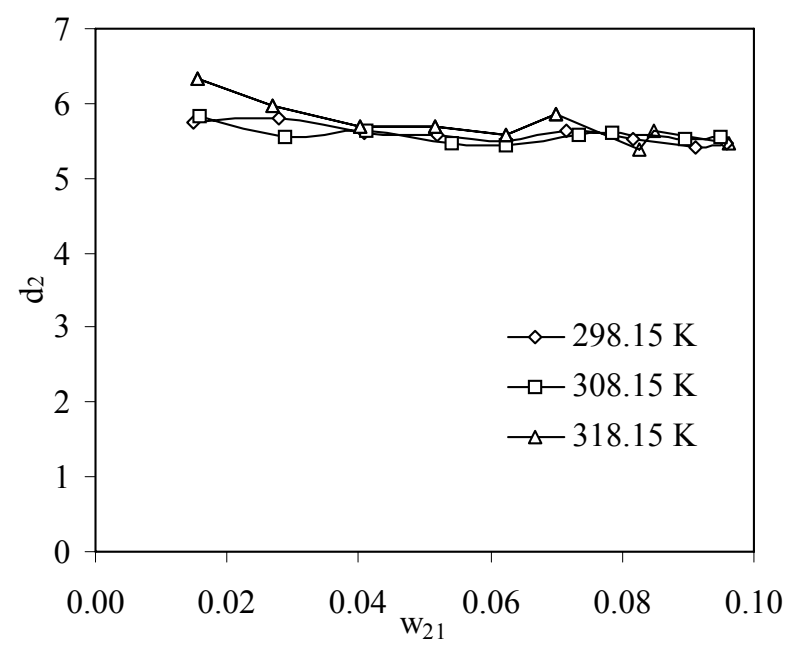

Figure 5: Distribution coefficient, $\mathrm{d}_{2}$, for butyric acid as a function of the mass fraction, $\mathrm{w}_{21}$, of butyric acid in aqueous phase.

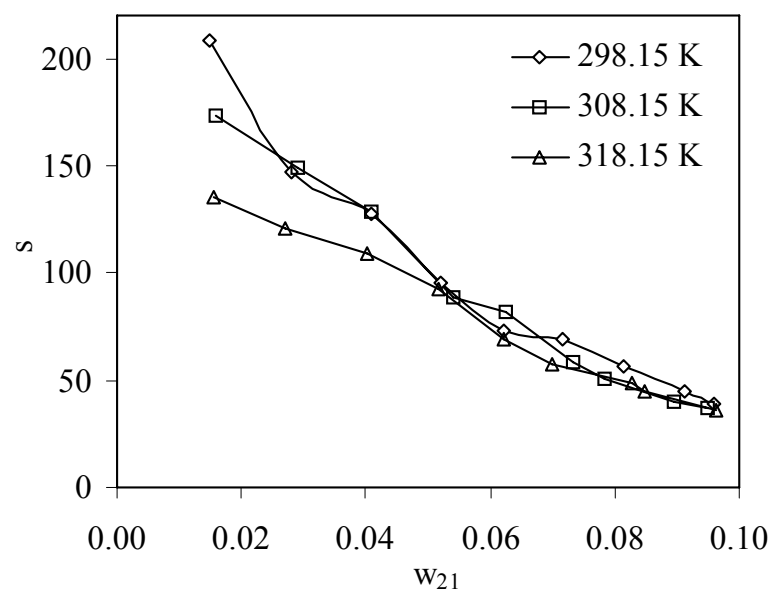

Figure 6: Separation factor, $s$, as a function of the mass fraction, $\mathrm{W}_{21}$, of butyric acid in the aqueous phase.

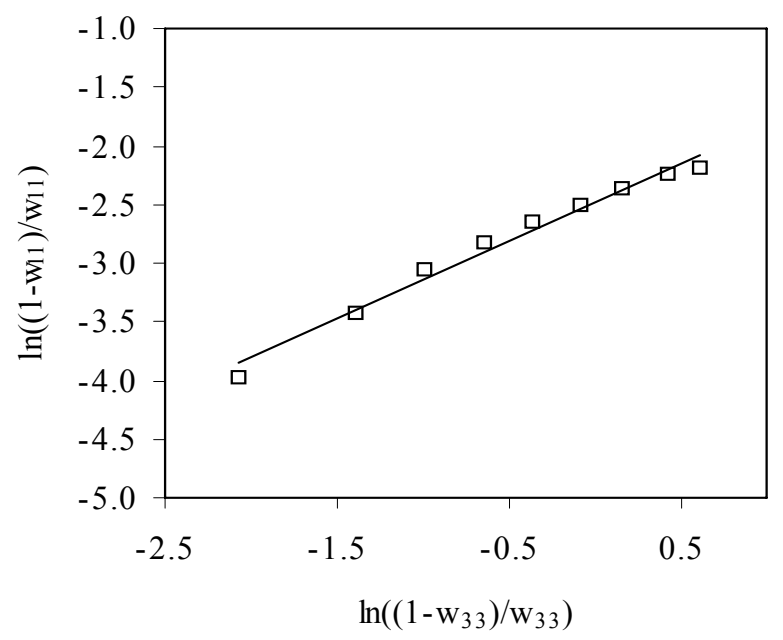

Figure 7: Othmer-Tobias plot of the (water + butyric acid + decanol) ternary system at $298.15 \mathrm{~K}$. 


\section{Prediction of Equilibria by the UNIFAC Method}

The LLE data of the ternary system were predicted by UNIFAC using the interaction parameters for $\mathrm{CH}_{3}, \mathrm{CH}_{2}, \mathrm{COOH}, \mathrm{OH}$ and $\mathrm{H}_{2} \mathrm{O}$ functional groups obtained by Magnussen et al. (1981). The values of the UNIFAC parameters for LLE prediction are summarised in Table 5. As shown in Figures 2, 3 and 4, LLE relations predicted by the UNIFAC method could not adequately fit the experimental LLE data. The discrepancy between the experimental and predicted solubilities does not change with temperature because the predicted and experimental data are practically independent of temperature.

The root mean square deviations (rmsd) were calculated from the difference between the experimental data and the predictions of the UNIFAC model at each temperature according to the following formula:

$$
\operatorname{rmsd}=\left\{\sum_{K}\left[\sum_{I} \sum_{J}\left(X_{i, \text { exp }}-X_{i, \text { calcd }}\right)^{2}\right] / 6 N\right\}^{1 / 2}
$$

The UNIFAC method was used to predict the experimental data 0.6643 at $\mathrm{T}=298.15 \mathrm{~K}, 0.6087$ at $\mathrm{T}=308.15 \mathrm{~K}$ and 0.6799 at $\mathrm{T}=318.15 \mathrm{~K}$ with $\mathrm{rmsd}$ values.

Selectivity diagrams on a solvent-free basis were obtained by plotting $\mathrm{w}_{23} /\left(\mathrm{w}_{23}+\mathrm{w}_{13}\right)$ vs. $\mathrm{w}_{21} /\left(\mathrm{w}_{21}+\mathrm{w}_{11}\right)$ for each temperature in Figure 8. The effect of a temperature change on the selectivity values was found to be insignificant.

Table 5: UNIFAC parameters for prediction (Magnussen et al., 1981).

\begin{tabular}{|l|c|c|c|c|c|c|c|}
\hline & $\mathbf{C H}_{\mathbf{3}}$ & $\mathbf{C H}_{\mathbf{2}}$ & $\mathbf{C O O H}$ & $\mathbf{O H}$ & $\mathbf{H}_{\mathbf{2}} \mathbf{O}$ & $\mathbf{R}_{\mathbf{k}}$ & $\mathbf{Q}_{\mathbf{k}}$ \\
\hline $\mathbf{C H}_{\mathbf{3}}$ & 0 & 0 & 1744 & 328.2 & 342.4 & 0.9011 & 0.8480 \\
$\mathbf{C H}_{\mathbf{2}}$ & 0 & 0 & 1744 & 328.2 & 342.4 & 0.6744 & 0.5400 \\
$\mathbf{C O O H}$ & 139.4 & 139.4 & 0 & -104 & -465.7 & 1.3013 & 1.2240 \\
$\mathbf{O H}$ & 644.6 & 644.6 & 118.4 & 0 & -122.4 & 1.0000 & 1.2000 \\
$\mathbf{H}_{\mathbf{2}} \mathbf{O}$ & 1300 & 1300 & 652.3 & 28.73 & 0 & 0.9200 & 1.4000 \\
\hline
\end{tabular}

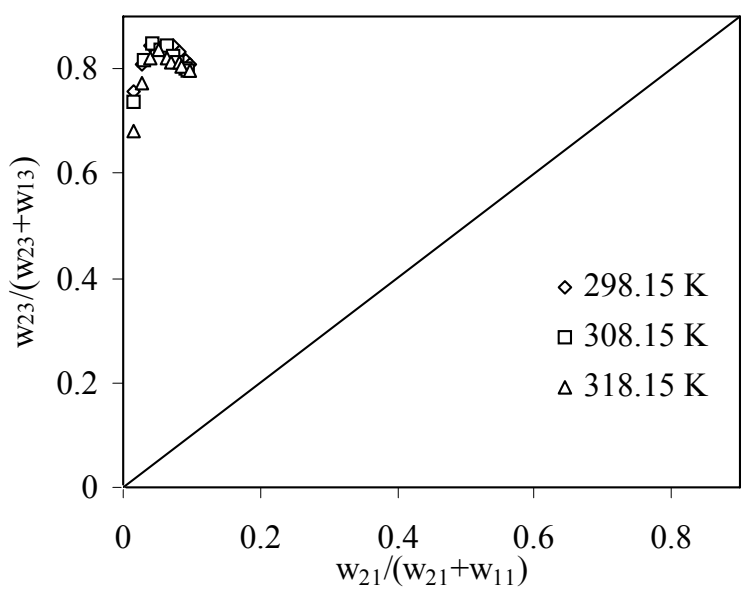

Figure 8: Selectivity diagram at temperatures studied (free-solvent basis).

\section{CONCLUSIONS}

LLE data on the water + butyric acid + decanol system were determined experimentally at 298.15, 308.15 and $318.15 \mathrm{~K}$. The temperature had a small effect on the size of the immiscibility region at the temperatures considered. It was shown that butyric acid was more soluble in solvent-rich phase than that in water-rich phase. Separation factors decreased with an increase in the concentration butyric acid, as can be seen in Table 4 .

The separation of butyric acid from water by extraction using decanol is feasible, as can be seen from distribution coefficient and separation factor data. In addition, it was found that the UNIFAC model predictions that did not fitted satisfactorily, but agreed qualitatively with the experimental data. 
Finally, it is concluded that decanol can be a suitable separation agent for dilute aqueous butyric acid.

\section{ACKNOWLEDGEMENT}

This work was supported by The Research Fund of Istanbul University, Project number: T$35 / 23072003$. I thank Sema Yüksel for helping during the experimental studies.

\section{NOMENCLATURE}

\begin{tabular}{|c|c|}
\hline $\mathrm{a}, \mathrm{b}$ & coefficients of the Othmer-Tobias \\
\hline$d_{i}$ & $\begin{array}{l}\text { equation, Eq. } 4 . \\
\text { distribution coefficient of the } i^{\text {th }} \\
\text { component. Eq. } 2 \text {. }\end{array}$ \\
\hline E & extract (solvent rich) phase, Eq. 1. \\
\hline i & $\begin{array}{l}\text { component number: water (1), butyric acid } \\
\text { (2) and decanol ( } 3 \text { ). }\end{array}$ \\
\hline & water, butyric acid or decanol, Eq. 5. \\
\hline $\mathrm{J}$ & solvent-rich or water-rich phase, Eq. 5. \\
\hline $\mathrm{K}$ & tie-line number $(1,2,3 \ldots \mathrm{N})$, Eq. 5 \\
\hline LLE & liquid-liquid equilibrium. \\
\hline $\mathrm{N}$ & $\mathrm{N}$ tie-line number $(\mathrm{N}=9)$, Eq. 5 . \\
\hline $\mathrm{Q}_{\mathrm{k}}$ & $\begin{array}{l}\text { relative van der Waals surface of } \\
\text { subgroup. }\end{array}$ \\
\hline $\mathrm{R}$ & raffinate (water-rich) phase, Eq. 1. \\
\hline $\mathrm{R}_{\mathrm{k}}$ & $\begin{array}{l}\text { relative van der Waals volume of } \\
\text { subgroup. }\end{array}$ \\
\hline $\mathrm{s}$ & separation factor, Eq. 3. \\
\hline $\mathrm{T}$ & temperature, $\mathrm{K}$ \\
\hline$T_{b}$ & boiling point, $\mathrm{K}$ \\
\hline $\mathrm{w}_{\mathrm{i}}$ & weight fraction of component $i$ \\
\hline $\mathrm{w}_{11}$ & $\begin{array}{l}\text { weight fraction of water (1) in the water- } \\
\text { rich phase }\end{array}$ \\
\hline $\mathrm{w}_{21}$ & $\begin{array}{l}\text { weight fraction of butyric acid (2) in the } \\
\text { water-rich phase }\end{array}$ \\
\hline $\mathrm{w}_{31}$ & $\begin{array}{l}\text { weight fraction of decanol ( } 3 \text { ) in the water- } \\
\text { rich phase }\end{array}$ \\
\hline $\mathrm{w}_{13}$ & $\begin{array}{l}\text { weight fraction of water (1) in the solvent- } \\
\text { rich phase }\end{array}$ \\
\hline $\mathrm{w}_{23}$ & $\begin{array}{l}\text { weight fraction of butyric acid (2) in the } \\
\text { solvent-rich phase }\end{array}$ \\
\hline $\mathrm{w}_{33}$ & $\begin{array}{l}\text { weight fraction of decanol ( } 3 \text { ) in the } \\
\text { solvent-rich phase }\end{array}$ \\
\hline Y & mole fraction of the component \\
\hline
\end{tabular}

\section{Greek Symbols}

$\rho \quad$ density $\left(\mathrm{g} / \mathrm{cm}^{3}\right)$
$n_{\mathrm{D}}$
refractive index
$\gamma$
activity coefficients of the component

\section{Subscripts}

$\begin{array}{ll}1 & \text { water } \\ 2 & \text { butyric acid } \\ 3 & \text { decanol } \\ \text { calcd. } & \text { calculated value } \\ \text { exp. } & \text { experimental value } \\ \text { i } & \text { component number, water, butyric acid, } \\ & \text { decanol, Eq. } 5 .\end{array}$

\section{Superscripts}

E extract (solvent rich) phase

$\mathrm{R}$ raffinate (water rich) phase

\section{REFERENCES}

Aljimaz, A.S., Fandary, M.S.H., Alkandary, J.A. and Fahim, M.A., Liquid-Liquid Equilibria of the Ternary System Water + Acetic Acid + 1Heptanol, J. Chem. Eng. Data, 45, 301 (2000).

Arce, A., Blanco, A., Souza, P. and Vidal, I., LiquidLiquid Equilibria of the Ternary Mixtures Water + Propionic Acid + Methyl Ethyl Ketone and Water + Propionic Acid + Methyl Propyl Ketone, J. Chem. Eng. Data, 40, 225 (1995).

Colombo, A., Battilana, P., Ragaini, V. and Bianchi, C.L., Liquid-Liquid Equilibria of the Ternary Systems Water + Acetic Acid + Ethyl Acetate and Water + Acetic Acid + Isophorone (3,3,5Trimethyl-cyclohexen-1one), J. Chem. Eng. Data, 44, 35 (1999).

Fahim, M.A., Qader, A. and Hughes, M.A., Extraction Equilibria of Acetic and Propionic Acids from Dilute Aqueous Solution by Several Solvents, Sep. Sci. Technol., 27, 1809 (1992).

Fahim, M.A. and Al-Muhtaseb, A.A., Liquid-Liquid Equilibria of the Ternary System Water + Acetic Acid + 2-Methyl-2-butanol, J. Chem. Eng. Data, 41, 1311 (1996).

Fahim, M.A., Al-Muhtaseb, A.A. and Al-Nashef, I.M., Liquid-Liquid Equilibria of the Ternary System Water + Acetic Acid + 1-Hexenol, J. Chem. Eng. Data, 42, 183 (1997).

Fredenslund, A., Jones, R.L. and Prausnitz, J.M., Group-Contribution Estimation of Activity Coefficients in Nonideal Liquid Mixtures, AIChE Journal, 21, 1086 (1975).

Hegazi, M.F., Influence of Hydrogen Bonding Acceptor Basicities of Esters and Ketones on the Extraction of Acetic and Butyric Acids from 
Aqueous Solutions, J. Chem. Tech. Biotechnol, 34A, 251 (1984).

İnce, E. and Kırbaşlar, Ş.İ., Liquid-Liquid Equilibria of the Water-Acetic Acid-Butyl Acetate System, Braz. J. Chem. Eng., 19, 243 (2002).

Ince, E., Liquid-Liquid Equilibria of the Ternary System Water + Acetic Acid + Dimethyl Adipate, Fluid Phase Equilib., 230, 58 (2005).

Lide, D.R., Handbook of Chemistry and Physics, $83^{\text {th }}$ Edition. CRC Press Inc., Boca Raton FL., Section 3 (2002).

Magnussen, T., Ramussen, P. and Fredenslund, A., UNIFAC Parameters Table for Prediction of Liquid-Liquid Equilibria, Ind. Eng. Chem. Process. Des. Dev., 20, 331 (1981).

Othmer, D.F. and Tobias, P.E., Tie-line Correlation, Ind. Eng. Chem., 34, 690 (1942).

Sólimo, H.N., Bonatti, C.M., Zurita, J.L. and de Doz, M.B.G., Liquid-Liquid Equilibria for the System Water +Propionic Acid + 1-Butanol at 303.2 K. Effect of Addition of Sodium Chloride, Fluid Phase Equilib., 137, 163 (1997).

Taghikhani, V., Vakili-Nezhaad, G.R., Khoshkbarchi,
M.K., and Shariaty-Niassar, M., Liquid-Liquid Equilibria of Water + Propionic Acid + Metyl Butyl Ketone and of Water + Propionic Acid + Metyl Isopropyl Ketone, J. Chem. Eng. Data, 46, 1107 (2001).

Trevor, M., Letcher, T.M. and Redhi, G.G., Phase Equilibria for Liquid Mixtures of (Benzonitrile + a Carboxylic acid + Water) at $\mathrm{T}=298.15 \mathrm{~K}, \mathrm{~J}$. Chem. Thermodyn., 33, 1555 (2001).

Wardell, J.M. and King, C.J., Solvent Equilibria for Extraction of Carboxylic Acids from Water, J. Chem. Eng. Data, 23, 144 (1978).

Zigová, J., Vandák, D., Schlosser, Š. and Šturdik, E., Extraction Equilibria of Butyric-Acid with Organic-Solvents, Sep. Sci. Technol., 31, 2671 (1996).

Zigová, J. Šturdik, E.,Vandák, D. and Schlosser, Š., Butyric Acid Production by Clostridium butyricum with Integrated Extraction and Pertraction, Process Biochem., 34, 835 (1999).

Zigová, J., and Šturdik, E., Advances in Biotechnological Production of Butyric Acid, J. Ind. Microbio. \& Biotech., 24, 153 (2000). 